\title{
Therapeutic Effects of AICAR and DOX Conjugated Multifunctional Nanoparticles in Sensitization and Elimination of Cancer Cells via Survivin Targeting
}

\author{
Cenk Daglioglu ${ }^{1,2}$ (D) B Burcu Okutucu ${ }^{2}$
}

Received: 14 June 2016 / Accepted: 14 October 2016 / Published online: 25 October 2016

(C) Springer Science+Business Media New York 2016

\begin{abstract}
Purpose Resistance to chemotherapy is one of the major problems facing current cancer research. Enhancing tumor cell response to anticancer agents increases chemotherapeutic effectiveness. We have recently addressed this issue and reported on producing multifunctional nanoparticles $\left(\mathrm{Fe}_{3} \mathrm{O}_{4} @ \mathrm{SiO}_{2}\right.$ (FITC)-FA/AICAR/DOX) aiming to overcome chemoresistance with synergetic effect of AICAR and DOX. In the present study, we demonstrated that these nanoparticles not only show enhanced cellular uptake and cytotoxic effect but can also show enhanced pro-apoptotic and antiproliferative effects in five different tumor-derived cell lines (A549, HCT-116, HeLa, Jurkat and MIA PaCa-2).
\end{abstract}

Methods The nanoparticles were examined by using flow cytometric analyses of apoptosis and cell cycle. In addition, we performed caspase-3 activity assay, which supported our flow cytometric data. Furthermore, we demonstrated the applicability of this approach in a variety of cancer types confirming the potential widespread utility of this approach.

Results With the concept of co-delivery of AICAR and DOX in the nanoparticle formulation, the use of AICAR against survivin (BIRC5) sensitized cancer cells to DOX chemotherapy which resulted in effective cancer cell elimination. These result showed that combination therapy involving both a molecularly targeted therapy and chemotherapeutic agent has the ability to retain and enhance therapeutic efficacy.

Conclusion $\mathrm{Fe}_{3} \mathrm{O}_{4} @ \mathrm{SiO}_{2}$ (FITC)-FA/AICAR/DOX nanoparticles is superior to monotherapy via the synergetic effect

Cenk Daglioglu

cenkdaglioglu@iyte.edu.tr

Faculty of Science, Department of Molecular Biology and Genetics, Izmir Institute of Technology, Urla/zmir 35430, Turkey

2 Faculty of Science, Biochemistry Department, Ege University, Bornova/ Izmir 35040, Turkey of AICAR and DOX and also the nanoparticle formulation could overcome issues of toxicity with targeted therapy while maintaining the potent anticancer effects of AICAR and DOX.

KEY WORDS AICAR · chemoresistance · DOX . multifunctional nanoparticles · survivin

\begin{tabular}{|c|c|}
\hline \multicolumn{2}{|c|}{ ABBREVIATIONS } \\
\hline 7-ADD & 7-aminoactinomycin \\
\hline AICAR & $\begin{array}{l}\text { 5-aminoimidazole- } 4 \text {-carboxamide- } 1-\beta \text {-D } \\
\text { ribofuranoside }\end{array}$ \\
\hline APTES & 3-aminopropyltriethoxysilane \\
\hline DMEM & Dulbecco's modified Eagle medium \\
\hline DOX & Doxorubicin \\
\hline FA & Folic acid \\
\hline FACS & Fluorescence-activated cell sorting \\
\hline FBS & Fetal bovine serum \\
\hline FITC & Fluorescein isothiocyanate \\
\hline Hsp90 & Heat shock protein 90 \\
\hline IAPs & Inhibitors of apoptosis proteins \\
\hline PBS & Phosphate buffered saline \\
\hline PE-annexin- $V$ & Phycoerythrin-annexin-V \\
\hline $\mathrm{Pl}$ & Propidium iodide \\
\hline RPMI- 1640 & $\begin{array}{l}\text { Roswell Park Memorial Institute- } \\
1640 \text { medium }\end{array}$ \\
\hline
\end{tabular}

\section{INTRODUCTION}

A characteristic feature of human cancers is the lack of a proper apoptotic response upon treatment with chemotherapeutic agents (1). Therefore, evasion of apoptosis constitutes a critical cause of drug resistance that frequently occurs in various human cancers. Cancer cells are typically subject to a fairly small number of antiapoptotic proteins for their survival, 
(2) thus providing a strong reason for targeting these proteins therapeutically. Inhibitors of apoptosis proteins (IAPs) are a family of endogenous antiapoptotic proteins which play critical roles in suppression of apoptosis. High expression of IAPs in cancer cells has been shown to interfere with the efficacy of chemotherapy by activating the antiapoptotic program which produces resistance to chemotherapeutic agents (3). Thus, the inhibition of IAP members offers a novel perspective in the struggle against drug resistance. Survivin, a structurally unique member of the IAP family that acts as a suppressor of apoptosis and plays a central role in cell division, is rarely expressed in normal healthy tissues but upregulated in all human cancers (4). Because of this upregulation in malignancy and its functional involvement in apoptosis and proliferation, survivin is currently attracting considerable interest both as a potential cancer biomarker (5) and as a new molecular target for cancer treatment (6). Multiple studies showed that high levels of survivin in tumor cells confer resistance to a range of anticancer drugs (7). Indeed, in many of these reports, blocking or neutralizing the actions of survivin was found to enhance the response to multiple types of conventional cancer therapies (8).

As survivin is not a cell surface protein and does not have an intrinsic enzymatic activity, targeting of survivin for therapeutic purposes might be expected to be difficult. In addition, crystallographic data has revealed few potential drugable sites on survivin protein (9). Despite these problems, a multiplicity of strategies has been employed to target the expression/ function of survivin at the transcriptional or posttranslational levels (10). One of the important targets in these strategies is the heat shock protein 90 (Hsp90), a molecular chaperone that oversees the correct conformational development of polypeptides and protein refolding through sequential ATPase cycles and stepwise recruitment of co-chaperones. This adaptive pathway is extensively exploited in cancer, where Hsp90 ATPase activity is upregulated approximately 100-fold (11). A physical interaction between the Hsp90 ATPase domain and the survivin BIR domain, has been shown to be essential for the stability and function of survivin (12). Thus, targeting the survivin-Hsp90 complex provides a strategy to simultaneously disable multiple signaling pathways in tumors. This interaction structurally inhibited the chaperone activity and exhibited potent and selective anticancer activity in preclinical models by using an antibiotic derivative of 17-AAG and a peptidomimetic antagonist of shepherdin (13). More recently, Meli et al. used shepherdin as a scaffold to rationally identify low-molecular-weight compounds that may act as structurally novel Hsp90 inhibitors. They first reported that the non-peptidic small molecule 5aminoimidazole-4-carboxamide- $1-\beta$-D-ribofuranoside (AICAR) binds the Hsp90 N-terminal domain, mimicking the chemical and conformational properties of shepherdin. AICAR has been shown to destabilize several Hsp90 client proteins in vivo, including survivin, and to exhibit antiproliferative and proapoptotic activity in multiple tumor cell lines, while not affecting proliferation of an immortalized human fibroblast cell line (14).

Doxorubicin (DOX) is a common chemotherapeutic used in the treatment of a wide range of cancers because of its excellent anti-tumor activity (15). Resistance to this agent impairs treatment of cancer patients and is an obstacle to successful treatment (16). In addition, DOX has a relatively low therapeutic index and its clinical usage is limited due to acute and chronic toxicities such as immunosupression and cardiotoxicity (17). Therefore, more efficient treatment strategies must be developed that reduce or eliminate drug resistance, decrease the cytotoxic effects of DOX and also enhance therapeutic efficacy. To address this problem, we have previously established a multifunctional nanoparticle platform $\left(\mathrm{Fe}_{3} \mathrm{O}_{4} @ \mathrm{SiO}_{2}(\mathrm{FITC})-\mathrm{FA} / \mathrm{AICAR} / \mathrm{DOX}\right)$ and demonstrated its capability in cellular uptake and cytotoxic effect in five different tumor-derived cell lines (A549, HCT-116, HeLa, Jurkat and MIA PaCa-2) (18).

In the present study, we took the application of this platform to the next step and investigated its proapoptotic and cell proliferation inhibition effects in the same cancer cell lines with its four different forms to evaluate the synergistic potential of therapeutics separately: (1) $\mathrm{Fe}_{3} \mathrm{O}_{4} @ \mathrm{SiO}_{2}$ (FITC)-FA nanoparticles without any inhibitor or drug used as control; (2) $\mathrm{Fe}_{3} \mathrm{O}_{4} @ \mathrm{SiO}_{2}(\mathrm{FITG})-\mathrm{FA} / \mathrm{AICAR}$ nanoparticles containing only inhibitor; (3) $\mathrm{Fe}_{3} \mathrm{O}_{4} @ \mathrm{SiO}_{2}(\mathrm{FITC})-\mathrm{FA} / \mathrm{DOX}$ nanoparticles containing only drug; (4) $\mathrm{Fe}_{3} \mathrm{O}_{4} @ \mathrm{SiO}_{2}(\mathrm{FITC})-\mathrm{FA} /$ AICAR/DOX nanoparticles containing both inhibitor and drug. We examined these platforms by using flow cytometric analyses of apoptosis with 7-ADD/PE-annexin-V double staining and cell cycle with propidium iodide DNA staining. In addition, we performed caspase- 3 activity assay to reveal activation levels of caspase-3 in apoptosis, supporting our flow cytometric data. Furthermore, We used tumor-derived cell

Fig. I Apoptosis analysis of A549, HCT- I | 6, HeLa, Jurkat and MIA PaCa-2 cells by flow cytometry. (a) PE-annexin-V / 7-ADD double staining of cancer cells treated with $10 \mu \mathrm{g} / \mathrm{ml}$ concentration of ( I) $\mathrm{Fe}_{3} \mathrm{O}_{4} @ \mathrm{SiO}_{2}(\mathrm{FITC})-\mathrm{FA}(2)$ $\mathrm{Fe}_{3} \mathrm{O}_{4} @ \mathrm{SiO}_{2}$ (FITC)-FA/AICAR, (3) $\mathrm{Fe}_{3} \mathrm{O}_{4} @ \mathrm{SiO}_{2}(\mathrm{FITC})-\mathrm{FA} / \mathrm{DOX}$ or (4) $\mathrm{Fe}_{3} \mathrm{O}_{4} @ \mathrm{SiO}_{2}$ (FITC)-FA/AICAR/DOX nanoparticles. Viable cells labelled with PE-annexin-V(-)/7-ADD(-), early apoptotic cells labelled with PE-annexin-V(+ )/7-ADD (-) and apoptotic cells labelled with PE-annexin-V(+)/7-ADD $(+)$ in flow cytometric graphics. (b) The percent of double positive cells in A549, HCT- I 6, HeLa, Jurkat and MIA PaCa-2 cells treated with the nanoparticles. Non-treated cells were used as control. Each column represents the mean \pm $\mathrm{SD}$ of three independent experiments performed in triplicate $(n=3)$. Immobilization concentration of: AICAR on $\mathrm{Fe}_{3} \mathrm{O}_{4} @ \mathrm{SiO}_{2}(\mathrm{FITC})$-FA/AICAR nanoparticles is 6.1 $\mu \mathrm{M}$ per mg nanoparticles; DOX on $\mathrm{Fe}_{3} \mathrm{O}_{4} @ \mathrm{SiO}_{2}$ (FITC)-FA/DOX nanoparticles is $1.0 \mu \mathrm{M}$ per mg nanoparticles; AICAR and DOX on $\mathrm{Fe}_{3} \mathrm{O}_{4} @ \mathrm{SiO}_{2}$ (FITC)-FA/AICAR/DOX nanoparticles are $4.5 \mu \mathrm{M}$ and $0.7 \mu \mathrm{M}$ per $\mathrm{mg}$ nanoparticles respectively. Note that the amount of DOX conjugation on the surface of $\mathrm{Fe}_{3} \mathrm{O}_{4} @ \mathrm{SiO}_{2}(\mathrm{FITC})$-FA/AICAR/DOX nanoparticles is 30\% less than the surface of $\mathrm{Fe}_{3} \mathrm{O}_{4} @ \mathrm{SiO}_{2}(\mathrm{FITC})-\mathrm{FA} / D O X$ nanoparticles. 
a $\mathbf{A 5 4 9}$ Control

Fe304@SI02(FITC)-FA

Fe304@SIO2(FITC)-FA/AICAR
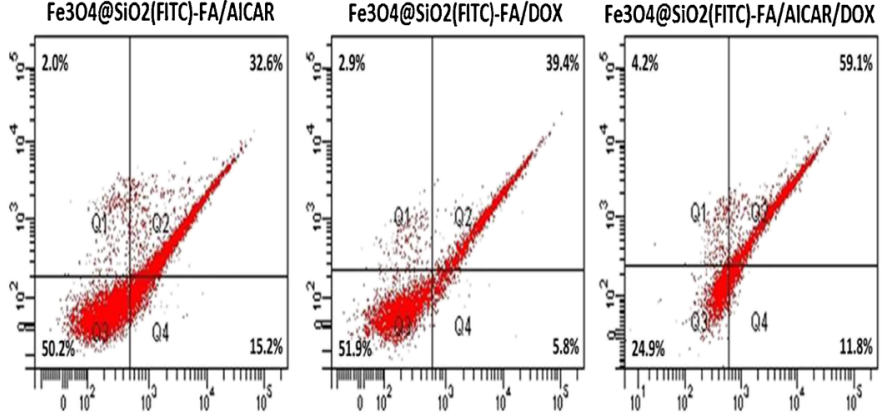

HCT-116
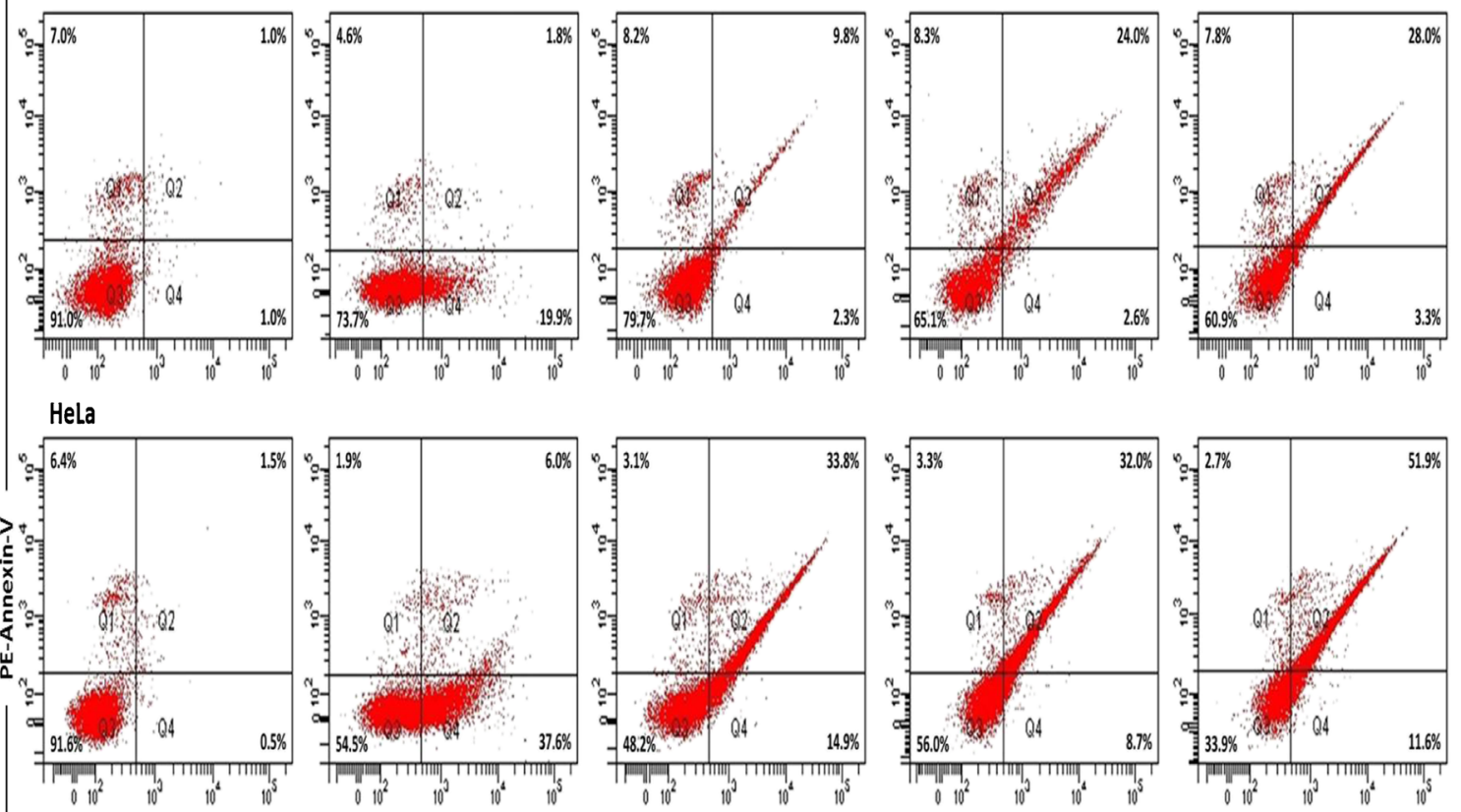

Jurkat
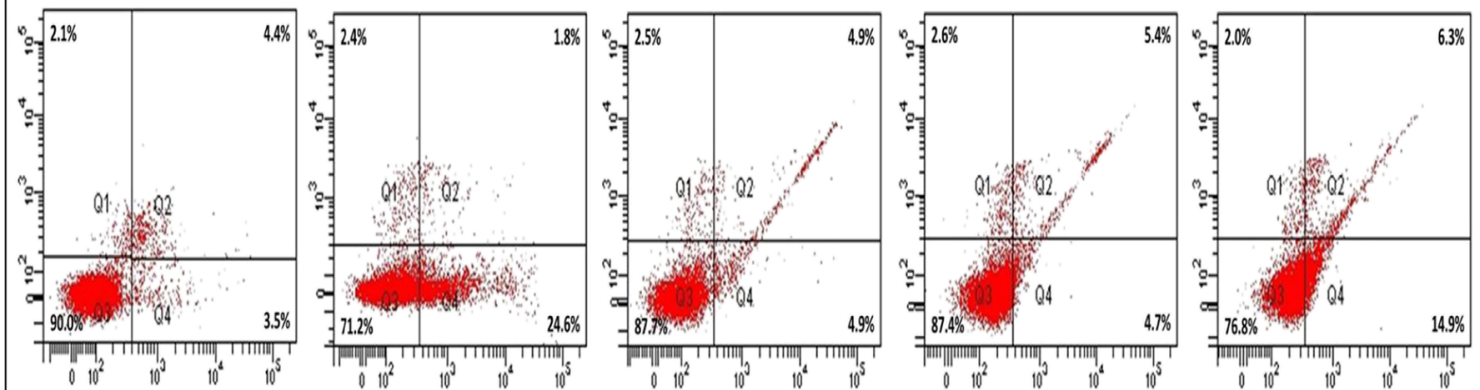

\section{MIA PaCa-2}
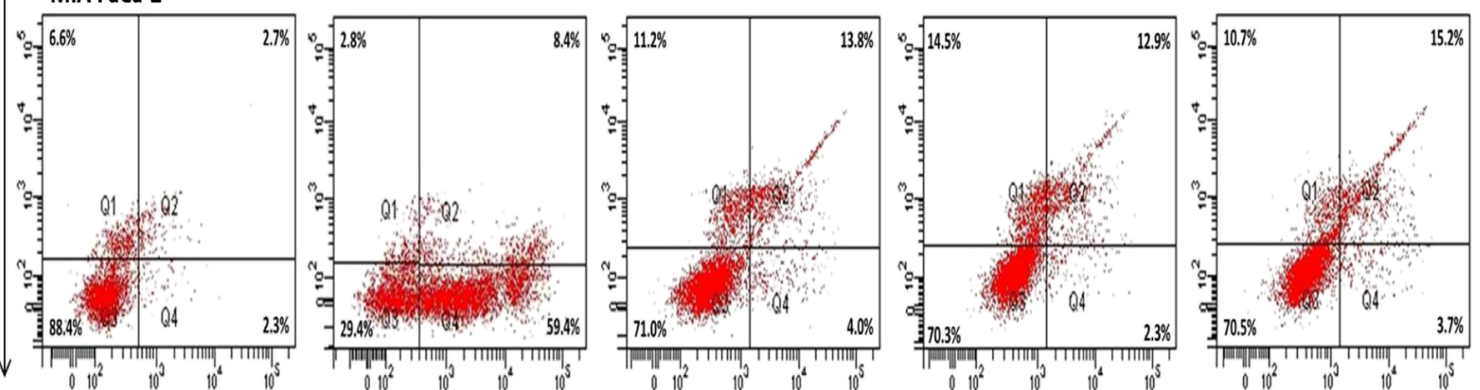

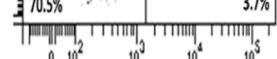




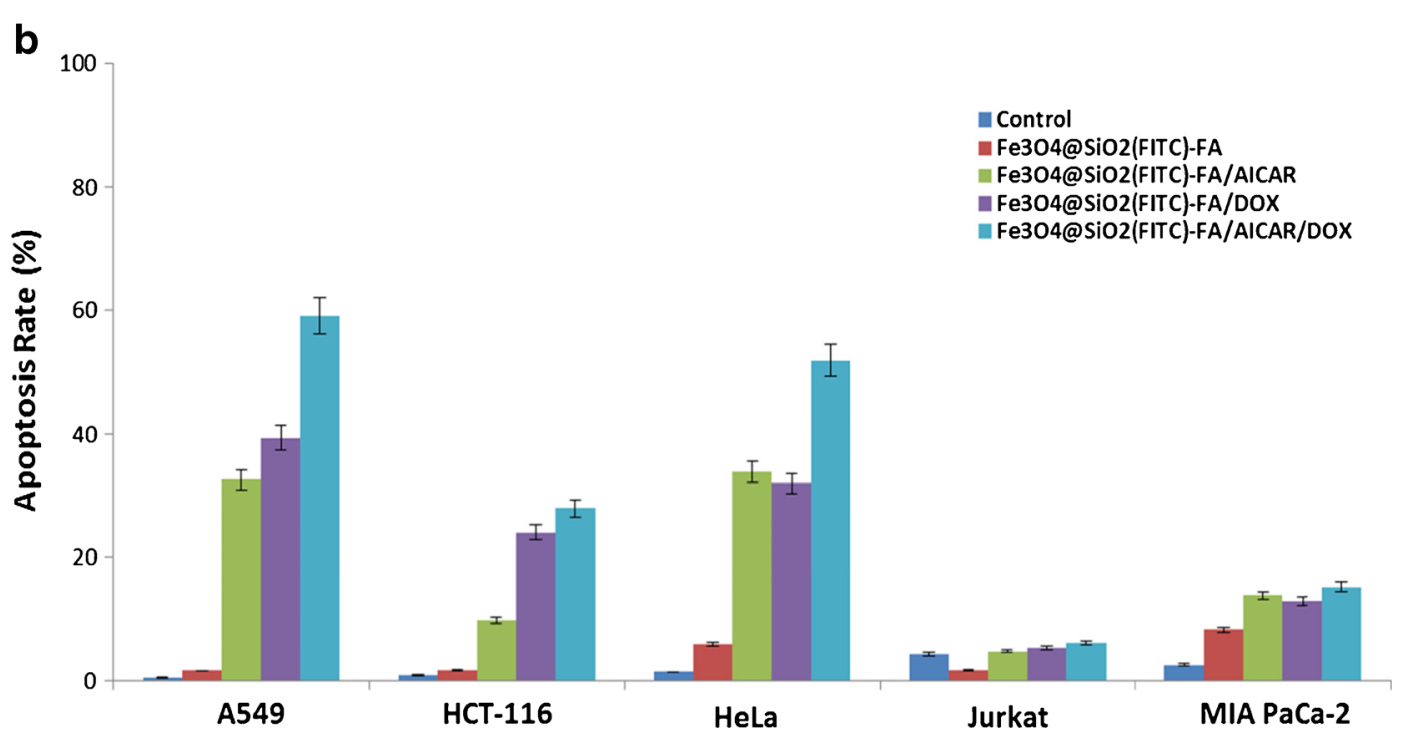

Fig. I continued.

lines with native differences in their biochemical profile as diverse as lung, colon colorectal, cervix, pancreatic carcinoma and acute T-cell leukemia, to investigate the cell-type specific impact of the nanoparticles and thus to demonstrate the applicability of this approach in a variety of cancer types confirming the potential widespread utility of this approach.

\section{MATERIAL AND METHODS}

\section{Materials}

Propidium iodide (PI), RNase A and trypsin were purchased from Sigma-Aldrich Chemicals. DMEM growth medium, RPMI1640 growth medium, 10\% Fetal bovine serum (FBS), streptomycin, penicillin and L-glutamic acid were purchased from Gibco Life technologies. BCA protein assay kit was purchased from Thermo Fisher Scientific. 7-aminoactinomycin (7-ADD) and PE-annexin-V were purchased from BD Biosciences. Caspase-3 colorimetric assay kit was purchased from BioVision, Inc (USA). All other chemicals and reagents were of the highest purity. All experiments were performed with deionized Milli-Qwater.

\section{Cell Cultures}

A549 (human epithelial lung carcinoma), HCT-116 (human epithelial colorectal carcinoma), HeLa (human epithelial cervical carcinoma), Jurkat (human acute T-cell leukemia) and MIA PaCa-2 (human epithelial pancreatic carcinoma) cell lines were kindly provided by Biotechnology and Bioengineering Research and Application Centre, Izmir Institute of Technology, Turkey. A549, HCT-116, HeLa and MIA PaCa-2 cancer cells were cultured in Dulbecco's modified Eagle medium (DMEM) supplemented with 10\% fetal bovine serum (FBS), $100 \mu \mathrm{g} / \mathrm{ml}$ streptomycin, 100 $\mathrm{U} / \mathrm{ml}$ penicillin and $2 \mathrm{mM}$ L-glutamic acid. Jurkat cancer cells were cultured in Roswell Park Memorial Institute-1640 (RPMI-1640) growth medium supplemented with $10 \%$ fetal bovine serum (FBS), $100 \mu \mathrm{g} / \mathrm{ml}$ streptomycin, $100 \mathrm{U} / \mathrm{ml}$ penicillin and $2 \mathrm{mM}$ L-glutamic acid. All cell lines were incubated in $5 \% \mathrm{CO}_{2}$ and $90-100 \%$ relative humidity at $37^{\circ} \mathrm{C}$. Medium renewal was carried out 2 to 3 times per week, and cells were subcultured when they achieved 80-90\% confluence. All cell lines were discarded after 20 generations, and new lines were obtained from frozen stocks.

\section{Nanoparticles Synthesis and Characterization}

The $\mathrm{Fe}_{3} \mathrm{O}_{4} @ \mathrm{SiO}_{2}(\mathrm{FITC})-\mathrm{FA} / \mathrm{AICAR} / \mathrm{DOX}$ nanoparticles were synthesized in our previous work as described in Ref. 18. Briefly, $\mathrm{Fe}_{3} \mathrm{O}_{4}$ nanocrystals were synthesized by a simple

Fig. 2 Apoptosis analysis of A549, HCT- I | 6, HeLa, Jurkat and MIA PaCa-2 cells by flow cytometry. (a) PE-annexin-V / 7-ADD double staining of cancer cells treated with $50 \mu \mathrm{g} / \mathrm{ml}$ concentration of (I) Fe $\mathrm{F}_{3} @ \mathrm{SiO}_{2}(\mathrm{FITC})-\mathrm{FA}$ (2) $\mathrm{Fe}_{3} \mathrm{O}_{4} @ \mathrm{SiO}_{2}$ (FITC)-FA/AICAR, (3) $\mathrm{Fe}_{3} \mathrm{O}_{4} @ \mathrm{SiO}_{2}(\mathrm{FITC})-\mathrm{FA} / \mathrm{DOX}$ or (4) $\mathrm{Fe}_{3} \mathrm{O}_{4} @ \mathrm{SiO}_{2}(\mathrm{FITC})-\mathrm{FA} / \mathrm{AICAR} / \mathrm{DOX}$ nanoparticles. Viable cells labelled with PE-annexin-V(-)/7-ADD(-), early apoptotic cells labelled with PE-annexin-V(+ )/7-ADD (-) and apoptotic cells labelled with PE-annexin-V(+)/ 7-ADD $(+)$ in flow cytometric graphics. (b) The percent of double positive cells in A549, HCT- I I 6, HeLa, Jurkat and MIA PaCa-2 cells treated with the nanoparticles. Non-treated cells were used as control. Each column represents the mean \pm $\mathrm{SD}$ of three independent experiments performed in triplicate $(n=3)$. Immobilization concentration of: AICAR on $\mathrm{Fe}_{3} \mathrm{O}_{4} @ \mathrm{SiO}_{2}$ (FITC)-FAJAICAR nanoparticles is 6.1 $\mu \mathrm{M}$ per mg nanoparticles; DOX on $\mathrm{Fe}_{3} \mathrm{O}_{4} @ \mathrm{SiO}_{2}$ (FITC)-FA/DOX nanoparticles is $1.0 \mu \mathrm{M}$ per mg nanoparticles; AICAR and DOX on $\mathrm{Fe}_{3} \mathrm{O}_{4} @ \mathrm{SiO}_{2}$ (FITC)-FA/AICAR/DOX nanoparticles are $4.5 \mu \mathrm{M}$ and $0.7 \mu \mathrm{M}$ per mg nanoparticles respectively. Note that the amount of DOX conjugation on the surface of $\mathrm{Fe}_{3} \mathrm{O}_{4} @ \mathrm{SiO}_{2}(\mathrm{FITC})-\mathrm{FA} / \mathrm{AICAR} / \mathrm{DOX}$ nanoparticles is $30 \%$ less than the surface of $\mathrm{Fe}_{3} \mathrm{O}_{4} @ \mathrm{SiO}_{2}(\mathrm{FITC})-\mathrm{FA} / \mathrm{DOX}$ nanoparticles. 

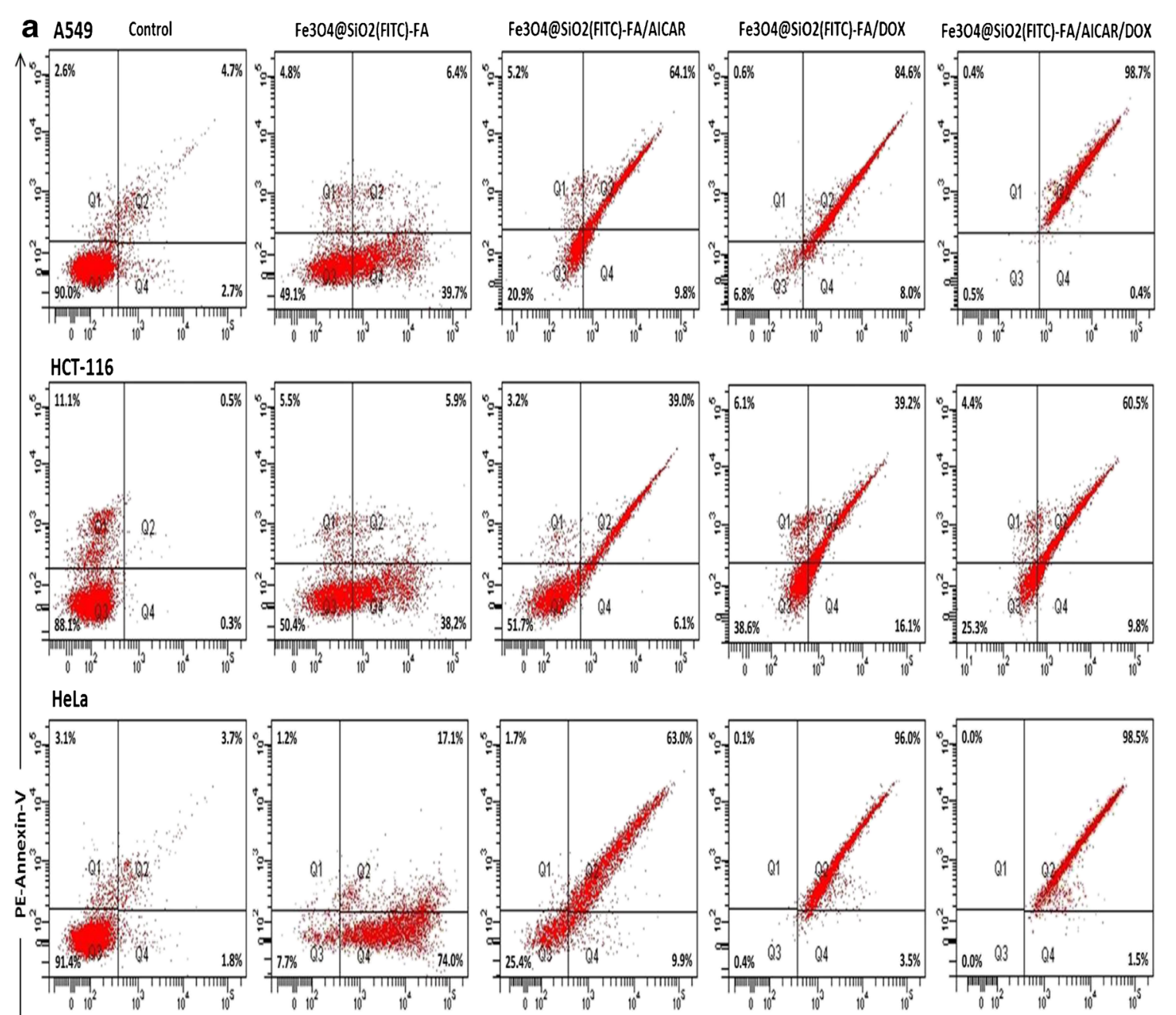

Jurkat
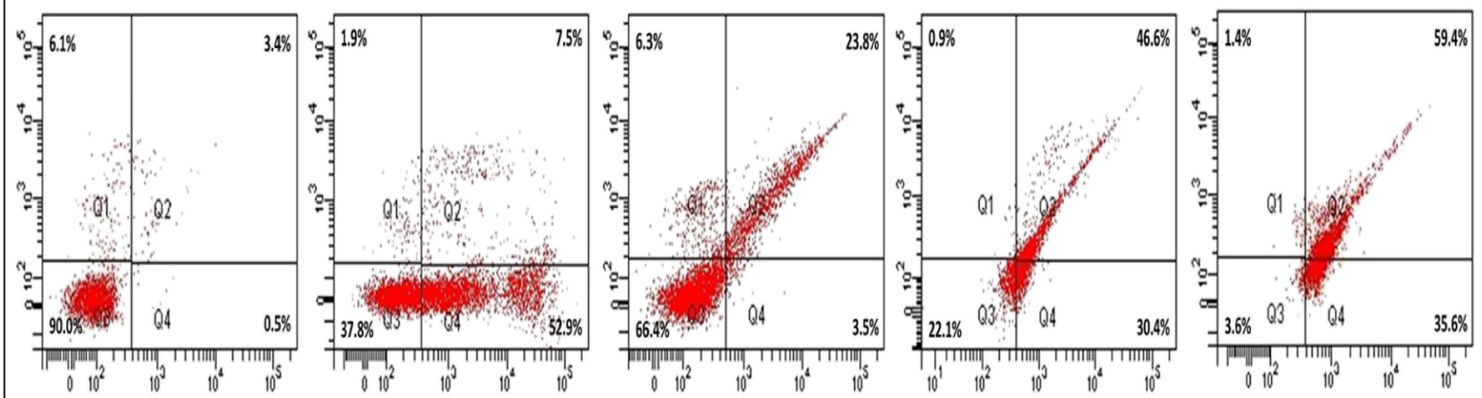

\section{MIA PaCa-2}
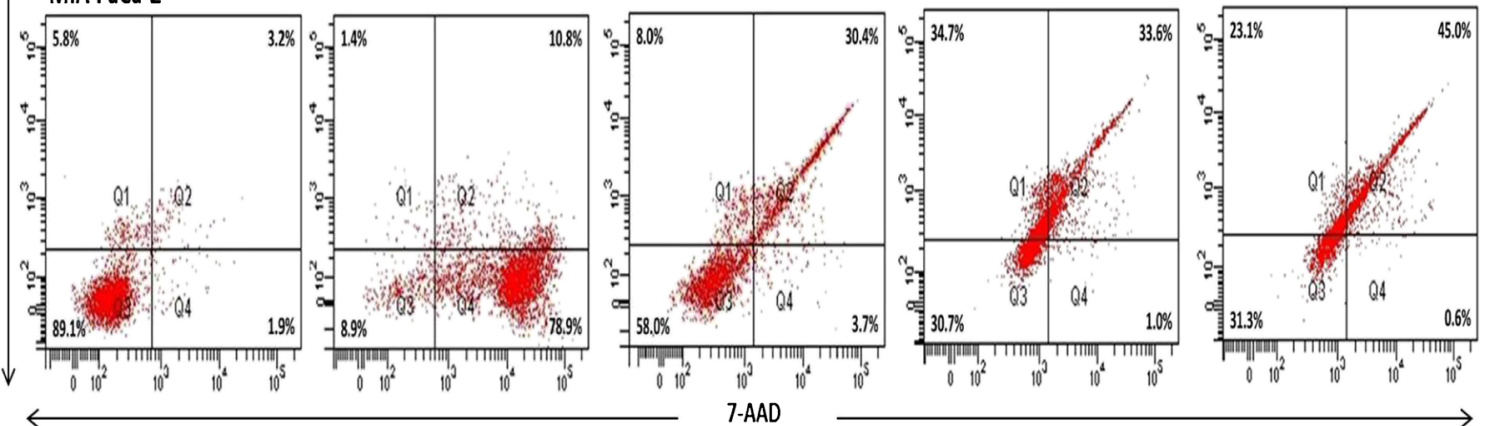


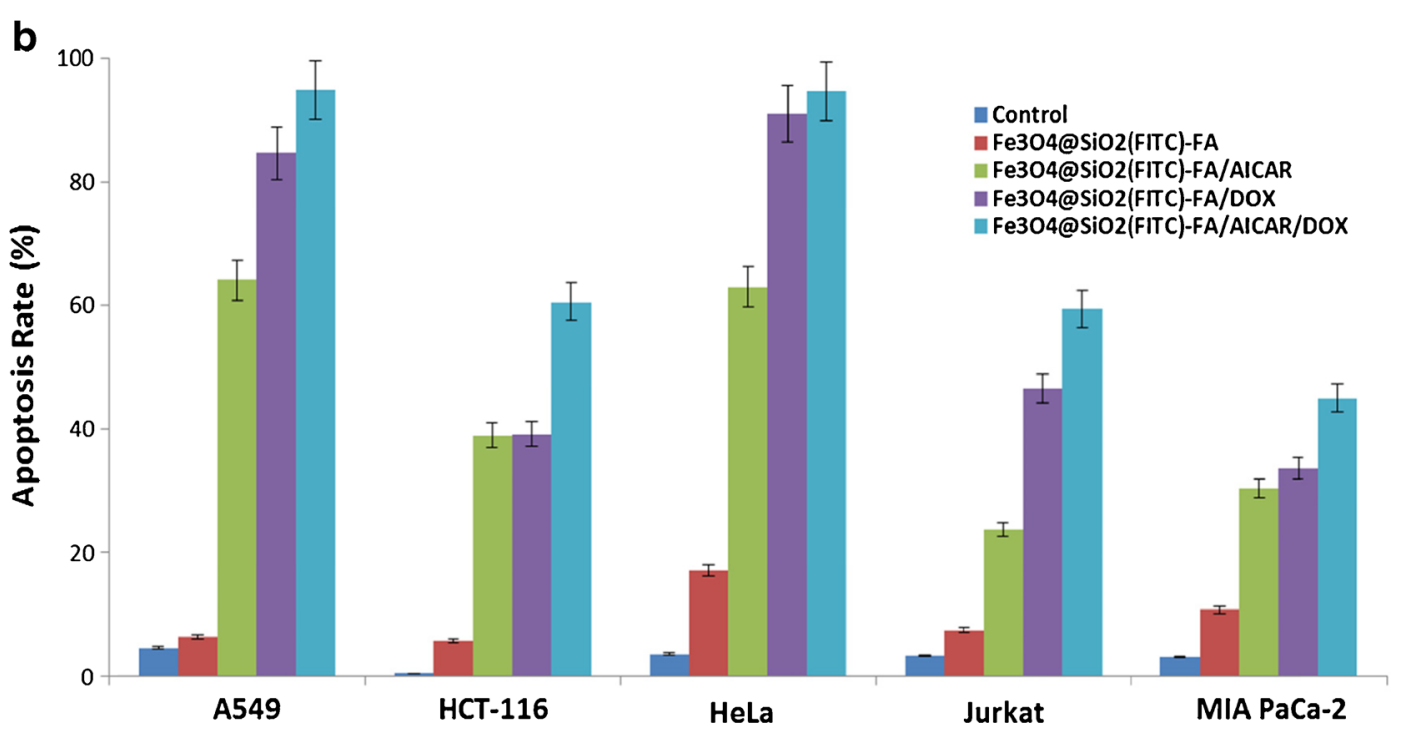

Fig. 2 continued.

co-precipitation of $\mathrm{Fe}^{+2} / \mathrm{Fe}^{+3}$ salts and then microemulsion sol-gel chemistry was used to construct layers of silica shells for colloidal protection, dye-doping and molecular functionalization. In this step, fluorescent dye (FITC) was chemically encapsulated into the silica shell to enhance photochemical stability and to protect the dye leaching into the reaction medium under harsh conditions. FA molecules were then covalently immobilized on $\mathrm{Fe}_{3} \mathrm{O}_{4} @ \mathrm{SiO}_{2}$ (FITC) structure by esterification and mediation of the 3aminopropyltriethoxysilane (APTES) to specific and efficient delivery of nanoparticles into cancer cells. Lastly, amine modified $\mathrm{Fe}_{3} \mathrm{O}_{4} @ \mathrm{SiO}_{2}(\mathrm{FITC})-\mathrm{FA} / \mathrm{NH}_{2}$ structure was furnished with AICAR and DOX complexes by Schiff-base formation to combine therapeutic functionalities in a single platform.

The structure of the newly synthesized nanoparticles was confirmed by different physicochemical characterization techniques: dynamic light scattering (DLS), X-ray diffraction
(XRD), Fourier transform infrared spectroscopy (FT-IR), thermogravimetric analysis (TGA), energy-dispersive $\mathrm{X}$-ray spectroscopy (EDX) and scanning/transmission electron microscopy (SEM and STEM). Additionally, the feasibility of nanoparticles was first evaluated by investigating their capability in cellular uptake, fluorescent imaging and cytotoxic effect in five different tumor-derived cell lines (A549, HCT116, HeLa, Jurkat and MIA PaCa-2).

\section{Detection of Apoptotic Cells by Flow Cytometry}

The percentage of cells undergoing apoptosis induced by nanoparticles was measured using flow cytometry with 7ADD and PE-annexin- $V$ double staining. A549, HCT116, HeLa, Jurkat and MIA PaCa-2 cells $\left(1 \times 10^{5}\right.$ cells/ well) were seeded in 6-well plates with $2 \mathrm{ml}$ of medium overnight before experiments. (1) $\mathrm{Fe}_{3} \mathrm{O}_{4} @ \mathrm{SiO}_{2}(\mathrm{FITC})-\mathrm{FA}$
Fig. 3 Effects of (I)

$\mathrm{Fe}_{3} \mathrm{O}_{4} @ \mathrm{SiO}_{2}(\mathrm{FITC})-\mathrm{FA}(2)$

$\mathrm{Fe}_{3} \mathrm{O}_{4} @ \mathrm{SiO}_{2}$ (FITC)-FAIAICAR, (3)

$\mathrm{Fe}_{3} \mathrm{O}_{4} @ \mathrm{SiO}_{2}(\mathrm{FITC})-\mathrm{FA} / \mathrm{DOX}$ or

(4) $\mathrm{Fe}_{3} \mathrm{O}_{4} @ \mathrm{SiO}_{2}$ (FITC)-FA/AICAR/

DOX nanoparticles on caspase-3 activation of A549, HCT- I 6 ,

HeLa, Jurkat and MIA PaCa-2 cells.

Caspase-3 activity was measured in cell lysates after $48 \mathrm{~h}$ incubation by hydrolysis of fluorogenic substrate $\mathrm{N}$-acetyl-Asp-Glu-Val-Asp-pNA (DEVD-pNA). Each column

represents the mean values $( \pm S D)$ of three independent experiments $\left(n=3\right.$, Student's $t$ test, $\left.{ }^{*} p<0.00 \mathrm{I}\right)$ normalized to non-treated cells (taken as 100\%).

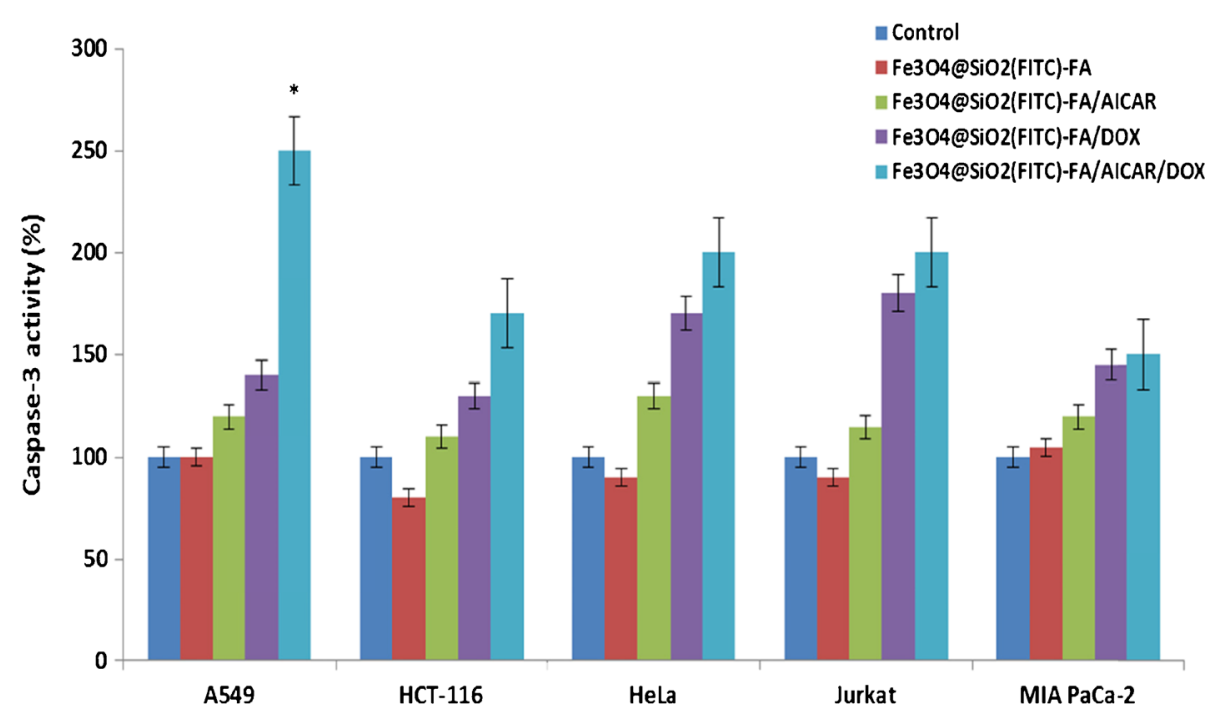


(2) $\mathrm{Fe}_{3} \mathrm{O}_{4} @ \mathrm{SiO}_{2}(\mathrm{FITC})-\mathrm{FA} / \mathrm{AICAR},(3)$ $\mathrm{Fe}_{3} \mathrm{O}_{4} @ \mathrm{SiO}_{2}(\mathrm{FITC})-\mathrm{FA} / \mathrm{DOX}$ or $(4)$ $\mathrm{Fe}_{3} \mathrm{O}_{4} @ \mathrm{SiO}_{2}$ (FITG)-FA/AICAR/DOX nanoparticles were added into the incubation medium separately at 10 or $50 \mu \mathrm{g} / \mathrm{ml}$ concentrations and then the cells were incubated for $4 \mathrm{~h}$ to allow uptake of the nanoparticles in $5 \%$ $\mathrm{CO}_{2}$ at $37^{\circ} \mathrm{C}$. Before analysis, the cells were carefully washed with cold PBS, digested with trypsin (except Jurkat) and collected by centrifugation. The cells were washed twice with cold PBS, resuspended in $200 \mu \mathrm{l}$ of annexin binding buffer and stained with $10 \mu \mathrm{l}$ of 7 -ADD and PE-annexin-V. The stained cells were first incubated for $15 \mathrm{~min}$. at room temperature by protecting from light, and then analyzed by flow cytometry. The untreated cells incubated with medium alone were used as the controls. Unstained cells, cells stained with PE-annexin- $\mathrm{V}$ alone and cells stained with 7-AAD alone were used to set up compensation and quadrants. Flow cytometric analysis was performed on a FACS (Facscanto; Becton Dickinson, San Jose, CA) by counting 10,000 events.

\section{Caspase-3 Catalytic Activity Assay}

Changes in caspase-3 enzyme activity of the cells are an important sign of apoptosis. To assess the effect of combination therapy on cell death, caspase-3 activity was analyzed fluorometrically by means of the Caspase-3/CPP32 colorimetric assay kit according to the manufacturer's instructions (BioVision Inc, USA). For this purpose, A549, HCT-116, HeLa, Jurkat and MIA PaCa-2 cells $\left(5 \times 10^{5}\right.$ cells/well) were incubated with $50 \mu \mathrm{g} / \mathrm{ml}$ concentrations of nanoparticles for $48 \mathrm{~h}$ at $37^{\circ} \mathrm{C}$ under $5 \% \mathrm{CO}_{2}$. This method is based on the hydrolysis of the peptide substrate acetyl-Asp-Glu-Val-Asp pnitroanilide (DEVD-pNA) by caspase-3, resulting in the release of the p-nitroaniline moiety. p-Nitroaniline was measured at $405 \mathrm{~nm}$ using plate reader.

\section{Cell Cycle Analysis by Flow Cytometry}

To determine the antiproliferative effects of (1) $\mathrm{Fe}_{3} \mathrm{O}_{4} @ \mathrm{SiO}_{2}(\mathrm{FITC})-\mathrm{FA}(2) \mathrm{Fe}_{3} \mathrm{O}_{4} @ \mathrm{SiO}_{2}(\mathrm{FITG})-\mathrm{FA} /$ AICAR, (3) $\mathrm{Fe}_{3} \mathrm{O}_{4} @ \mathrm{SiO}_{2}(\mathrm{FITC})-\mathrm{FA} / \mathrm{DOX}$ or (4) $\mathrm{Fe}_{3} \mathrm{O}_{4} @ \mathrm{SiO}_{2}(\mathrm{FITG})-\mathrm{FA} / \mathrm{AICAR} / \mathrm{DOX}$ nanoparticles against A549, HCT-116, HeLa, Jurkat and MIA PaCa-2 cells, cell cycle distributions were analyzed by flow cytometry-based propidium iodide $(\mathrm{PI})$ staining. The cells $\left(1 \times 10^{5}\right.$ cells/well $)$ were seeded in 6 -well plates with $2 \mathrm{ml}$ of medium overnight before experiments and then incubated with $50 \mu \mathrm{g} / \mathrm{ml}$ concentrations of nanoparticles for $24 \mathrm{~h}$ at $37^{\circ} \mathrm{C}$ under $5 \% \mathrm{CO}_{2}$. After the incubation, the cells were trypsinized, washed once with PBS and fixed in 80\% ethanol overnight at $-20^{\circ} \mathrm{C}$. The next day, after centrifugation of fixed cells, the pellet washed with cold PBS and then resuspended in
DNA staining solution $[200 \mu \mathrm{l} 0.1 \%$ Triton $\mathrm{X}-100$ in PBS, $20 \mu \mathrm{l}(200 \mu \mathrm{g} / \mathrm{ml})$ RNase A and $20 \mu \mathrm{l}(1 \mathrm{mg} / \mathrm{ml})$ propidium iodide] for $30 \mathrm{~min}$ at room temperature. The stained cells were analyzed using flow cytometer. The fraction of the G0G1, S and G2-M phase of cells on DNA histograms was analyzed by ModFit software.

\section{Statistical Analysis}

All data were represented as means \pm standard deviation (SD) for triplicate experiments. Statistical analysis was performed with the Student's $t$ test, using Excel Software (Microsoft). A $P$ value of $\leq 0.05$ was considered statistically significant.

\section{RESULTS AND DISCUSSION}

\section{Detection of Apoptotic Cells by Flow Cytometry}

We investigated the impact of survivin inhibition with AICAR on DOX sensitivity by comparing apoptotic effects of the nanoparticles with both low-dose and $\mathrm{IC}_{50}$ concentrations $(10 / 50 \mu \mathrm{g} / \mathrm{ml})$ against A549, HCT-116, HeLa, Jurkat and MIA PaCa-2 cells. $\mathrm{Fe}_{3} \mathrm{O}_{4} @ \mathrm{SiO}_{2}(\mathrm{FITC})-\mathrm{FA} / \mathrm{AICAR} / \mathrm{DOX}$ nanoparticles, versus the other nanoparticles at low-dose $(10 \mu \mathrm{g} / \mathrm{ml})$ concentration, strongly increased the percent of double (PEannexin-V/ 7-ADD) positive apoptotic cells in A549 and HeLa cells to 59.1 and $51.9 \%$ while lower effects were observed in HCT-116, Jurkat and MIA PaCa-2 cells with the percents of $28.0 / 6.3 / 15.2 \%$, respectively (Fig. 1). When $50 \mu \mathrm{g} / \mathrm{ml}$ concentration of the nanoparticle was applied to the cells, nearly no viability was observed in A549, HeLa and Jurkat cells while 25\% of HCT-116 and $31 \%$ of MIA PaCa-2 cells were determined as viable (Fig. 2). $\mathrm{Fe}_{3} \mathrm{O}_{4} @ \mathrm{SiO}_{2}(\mathrm{FITC})-\mathrm{FA} / \mathrm{DOX}$ nanoparticles did not significantly increase apoptotic cell death compared to $\mathrm{Fe}_{3} \mathrm{O}_{4} @ \mathrm{SiO}_{2}$ (FITC)-FA/AICAR nanoparticles. Interestingly, treatment with nanoparticles conjugated with AICAR alone showed considerable apoptotic effect, confirming AICAR's functional involvement in apoptosis. Furthermore, we observed the induction of considerable levels of dose-dependent necrosis with $\mathrm{Fe}_{3} \mathrm{O}_{4} @ \mathrm{SiO}_{2}$ (FITC)-FA control nanoparticles in all cells, indicating that FA-linked nanocarriers successfully penetrated into the cells via folate-receptor mediation and caused necrotic (passive) cell death with accumulation of the vectors into the cancer cells. Overall, these results suggested that nanoparticles conjugated with DOX alone induced apoptosis in the cell. However, it also caused upregulation of survivin, lowering the level of apoptosis. The depletion of survivin by AICAR abolished this antiapoptotic effect and resulted in the most improved 
apoptotic rates in all cells with the synergistic effect of DOX. These results corroborated that survivin plays an important role in the drug-resistant phenotype of human cancer cells. Zaffaroni et al. reported that stable transfection of human ovarian cancer cell lines with survivin cDNA was able to protect them from the cytotoxic effects induced by taxol and taxotere (19). An increase in survivin expression has also been reported in colorectal cancer cells resistant to TNF-related apoptosis inducing ligand (TRAIL) (20). Asanuma et al. first reported that survivin acts as a constitutive radioresistance factor in pancreatic cancer cells (21). Olie et al. showed that anti-sense targeting of survivin sensitizes lung cancer cells to e toposide chemotherapy.(22) Briefly, $\mathrm{Fe}_{3} \mathrm{O}_{4} @ \mathrm{SiO}_{2}($ FITG)-FA/AICAR/DOX nanoparticles clearly advanced survivin neutralization resulting in an increased level of anticancer activity of apoptosisinducing agent in five different tumor derived cell lines. Thus, this work confirms the potential widespread utility of these multipurpose nanoparticles.

\section{Caspase-3 Catalytic Activity Analysis}

To determine the apoptotic effects of the nanoparticles on A549, HCT-116, HeLa, Jurkat and MIA PaCa-2 cells, the cells were also evaluated by measuring caspase- 3 activity, since caspase- 3 is a crucial component of apoptotic cell death. These cells were incubated with $50 \mu \mathrm{g} / \mathrm{ml}$ concentration of the nanoparticles for $48 \mathrm{~h}$ and changes in caspase- 3 enzyme activities were analyzed. Incubation of A549 cells with $\mathrm{Fe}_{3} \mathrm{O}_{4} @ \mathrm{SiO}_{2}$ (FITC)-FA/AICAR/DOX nanoparticles demonstrated significant $(p<0.001)$ induction of caspase-3 activity $(150 \%)$ when compared with untreated cells. Consistent with this result, we also found 70\% / 100\% / 100\% / \%50 increases in caspase- 3 activity in response to $48 \mathrm{~h}$ incubation on HCT-1 16, HeLa, Jurkat and MIA PaCa-2 cells, respectively (Fig. 3). On the other hand, we observed no increases in caspase-3 activity in the cells incubated with $\mathrm{Fe}_{3} \mathrm{O}_{4} @ \mathrm{SiO}_{2}$ (FITC)-FA control nanoparticles confirming the necrotic cell death obtained by flow cytometry. The results revealed that $\mathrm{Fe}_{3} \mathrm{O}_{4} @ \mathrm{SiO}_{2}(\mathrm{FITC})-\mathrm{FA} / \mathrm{AICAR} / \mathrm{DOX}$ nanoparticles led to the highest activation of caspase- 3 in the lung carcinoma A549 cell line, while also promoted the activation of caspase-3 on the colon carcinoma HCT-116, cervical carcinoma HeLa, the leukemia Jurkat, and the pancreatic carcinoma MIA PaCa-2 cell lines, which supports the anti-tumor effect of the nanoparticles for wide range of cancer types.

\section{Cell Cycle Analysis by Flow Cytometry}

One critical point of our study was to investigate differences in the proliferation of cancer cells following the nanoparticles incubation, with the expectation that synergistic inhibition of
Fig. 4 Effect of I) $\mathrm{Fe}_{3} \mathrm{O}_{4} @ \mathrm{SiO}_{2}(\mathrm{FITC})-\mathrm{FA}$ (2) $\mathrm{Fe}_{3} \mathrm{O}_{4} @ \mathrm{SiO}_{2}(\mathrm{FITC})-\mathrm{FA} /$ AICAR, (3) $\mathrm{Fe}_{3} \mathrm{O}_{4} @ \mathrm{SiO}_{2}(\mathrm{FITC})-\mathrm{FA} / \mathrm{DOX}$ or (4) $\mathrm{Fe}_{3} \mathrm{O}_{4} @ \mathrm{SiO}_{2}$ (FITC)-FA AICAR/DOX nanoparticles on the cell cycle distribution of A549, HCT- I I6, HeLa, Jurkat and MIA PaCa-2 cells determined by flow cytometry-based PI staining. Immobilization concentration of: AICAR on $\mathrm{Fe}_{3} \mathrm{O}_{4} @ \mathrm{SiO}_{2}(\mathrm{FITC})-\mathrm{FA}$ AICAR nanoparticles is 6.1 $\mu \mathrm{M}$ per mg nanoparticles; DOX on $\mathrm{Fe}_{3} \mathrm{O}_{4} @ \mathrm{SiO}_{2}$ (FITC)-FA/DOX nanoparticles is $1.0 \mu \mathrm{M}$ per mg nanoparticles; AICAR and DOX on $\mathrm{Fe}_{3} \mathrm{O}_{4} @ \mathrm{SiO}_{2}$ (FITC)-FA/AICAR/DOX nanoparticles are $4.5 \mu \mathrm{M}$ and $0.7 \mu \mathrm{M}$ per mg nanoparticles respectively. Note that the amount of DOX conjugation on the surface of $\mathrm{Fe}_{3} \mathrm{O}_{4} @ \mathrm{SiO}_{2}$ (FITC)-FA/AICAR/DOX nanoparticles is 30\% less than the surface of $\mathrm{Fe}_{3} \mathrm{O}_{4} @ \mathrm{SiO}_{2}(\mathrm{FITC})-\mathrm{FA} / \mathrm{DOX}$ nanoparticles.

the cells would promote the anti-proliferative effect. All of the cell lines treated with $\mathrm{Fe}_{3} \mathrm{O}_{4} @ \mathrm{SiO}_{2}(\mathrm{FITG})-\mathrm{FA} / \mathrm{AICAR} /$ DOX and $\mathrm{Fe}_{3} \mathrm{O}_{4} @ \mathrm{SiO}_{2}(\mathrm{FITC})-\mathrm{FA} / \mathrm{DOX}$ nanoparticles significantly depressed cell proliferation at the $\mathrm{G}_{2} / \mathrm{M}$ phase (Fig. 4). $\mathrm{Fe}_{3} \mathrm{O}_{4} @ \mathrm{SiO}_{2}$ (FITC)-FA/AICAR/DOX nanoparticles arrested more cells, especially in A549 and Jurkat cells at the $\mathrm{G}_{2} / \mathrm{M}$ phase compared with $\mathrm{Fe}_{3} \mathrm{O}_{4} @ \mathrm{SiO}_{2}($ FITC)FA/DOX nanoparticles. This implied that $\mathrm{Fe}_{3} \mathrm{O}_{4} @ \mathrm{SiO}_{2}($ FITG)-FA/AICAR/DOX nanoparticles have more cell cycle arrest capacity as compared with $\mathrm{Fe}_{3} \mathrm{O}_{4} @ \mathrm{SiO}_{2}$ (FITG)-FA/DOX nanoparticles. Consistent with these results, it has been suggested that survivin expression is predominantly regulated by a cell cycle dependent and cell cycle homology region within the promoter, which leads to maximum expression during the $\mathrm{G}_{2} / \mathrm{M}$ phase of the cell cycle (23). Li et al. showed that cells transfected with a mutant survivin gene or survivin anti-sense appeared to show increased caspase- 3 activity when synchronized in $G_{2} / M$ phase (24). The cell cycle distribution of the cells exposed to $\mathrm{Fe}_{3} \mathrm{O}_{4} @ \mathrm{SiO}_{2}$ (FITG)-FA/AICAR nanoparticles was found to be similar with the cells exposed to $\mathrm{Fe}_{3} \mathrm{O}_{4} @ \mathrm{SiO}_{2}(\mathrm{FITC})$ FA control nanoparticles and untreated cells. On the basis of these findings, we hypothesized that the concentration of $\mathrm{Fe}_{3} \mathrm{O}_{4} @ \mathrm{SiO}_{2}$ (FITC)-FA/AICAR nanoparticles was not sufficient alone to affect cell cycle arrest as seen in viability test in our previous work (18). Alternatively, there is a slight possibility that these nanoparticles induce apoptosis without cell cycle arrest.

\section{CONCLUSION}

The aim of this study was to test novel $\mathrm{Fe}_{3} \mathrm{O}_{4} @ \mathrm{SiO}_{2}(\mathrm{FITC})$ FA/AICAR/DOX multifunctional nanoparticles for neutralizing survivin with AICAR to potentiate the efficacy of DOX for targeted cancer therapy. We analyzed the impact of $\mathrm{Fe}_{3} \mathrm{O}_{4} @ \mathrm{SiO}_{2}($ FITC)-FA/AICAR/DOX nanoparticle treatments by comparing the nanoparticles conjugated with DOX or AICAR alone against the $\mathrm{Fe}_{3} \mathrm{O}_{4} @ \mathrm{SiO}_{2}(\mathrm{FITC})-\mathrm{FA}$ control nanoparticles. In this study, we also used tumorderived cell lines with native differences in their biochemical 


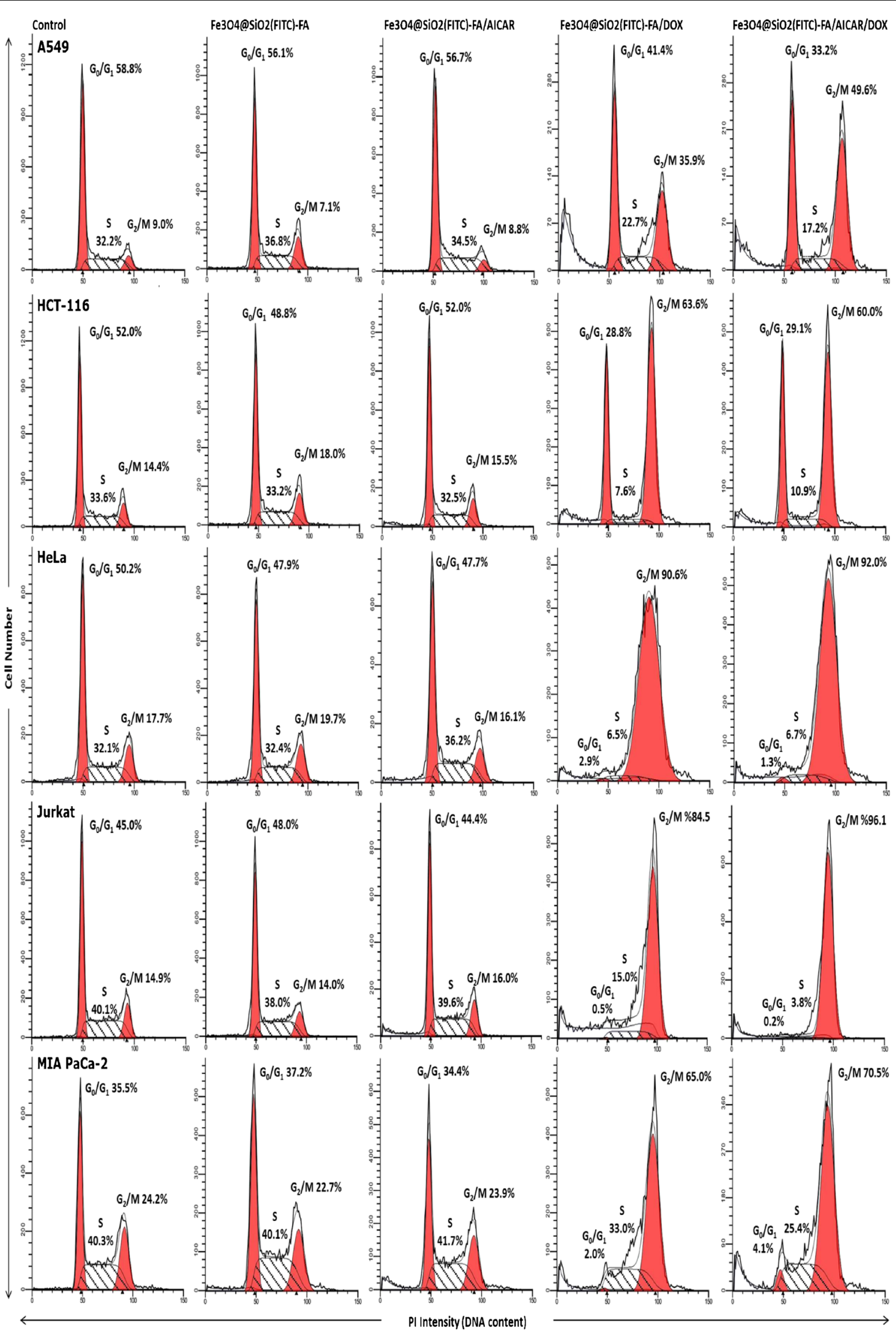


profile to investigate the potential widespread utility of the nanoparticles. It was found that the $\mathrm{Fe}_{3} \mathrm{O}_{4} @ \mathrm{SiO}_{2}(\mathrm{FITC})$ FA/AICAR/DOX nanoparticles significantly improved apoptosis rate while inhibiting cell proliferation of five different cancer cell lines. Our data indicate strong proapoptotic and antiproliferative effects of $\mathrm{Fe}_{3} \mathrm{O}_{4} @ \mathrm{SiO}_{2}(\mathrm{FITC})-\mathrm{FA} / \mathrm{AICAR} /$ DOX nanoparticles on the lung carcinoma cell line A549. The nanoparticles showed high proapoptotic effects at lowdose concentrations on the cervical carcinoma HeLa and the colon carcinoma HCT-116 cells, and at $\mathrm{IC}_{50}$ concentration on the leukemia Jurkat and the pancreatic carcinoma MIA $\mathrm{PaCa}-2$ cells, is consistent with previous study (25) that have demonstrated that resistance to chemotherapy correlates with expression levels of survivin in different tumor types, with the highest levels of expression in lung cancer lines followed by ovarian, colon and leukemia. We additionally assessed caspase-3 activity to reveal activation levels of caspase- 3 in apoptosis, which supported our flow cytometric data. Furthermore, the cell cycle distribution of cell lines showed that the nanoparticles arrest all cells in the $\mathrm{G}_{2} / \mathrm{M}$ phase confirming increased cell proliferation inhibition at the $\mathrm{G}_{2}$ / M checkpoint. Moreover, $\mathrm{Fe}_{3} \mathrm{O}_{4} @ \mathrm{SiO}_{2}(\mathrm{FITG})-\mathrm{FA} / \mathrm{AICAR} /$ DOX nanoparticles led to approximately a $30 \%$ decrease in the use of DOX in $\mathrm{Fe}_{3} \mathrm{O}_{4} @ \mathrm{SiO}_{2}$ (FITC)-FA/DOX nanoparticles, a reduction that is significant in a clinical context. These observations suggest that combination therapy with $\mathrm{Fe}_{3} \mathrm{O}_{4} @ \mathrm{SiO}_{2}$ (FITC)-FA/AICAR/DOX nanoparticles is not only superior to monotherapy via the synergetic effect of AICAR and DOX but also the nanoparticle formulation could overcome issues of toxicity while maintaining the potent anticancer effects of AICAR and DOX. However, further in vivo evaluation needs to be done to characterize more precisely the synergetic effect of AICAR and DOX in the concept of nanoparticle delivery system.

\section{ACKNOWLEDGMENTS AND DISCLOSURES}

The authors would like to thank Professor Anne Frary at the Izmir Institute of Technology for proofreading of the manuscript and Özgür Yılmazer from Biotechnology and Bioengineering Center of Izmir Institute of Technology for technical assistance during flow cytometry reading.

\section{REFERENCES}

1. Lockshin RA, Zakeri Z. Cell death in health and disease. J Cell Mol Med. 2007;11:1214-24.

2. Letai AG. Diagnosing and exploiting cancer's addiction to blocks in apoptosis. Nat Rev Cancer. 2008;8:121-32.

3. Fulda S, Vucic D. Targeting IAP proteins for therapeutic intervention in cancer. Nat Rev Drug Disc. 2012;11:109-24.

4. Li F. Survivin study: what is the next wave? J Cell Physiol. 1971;2003:8-29.
5. Duffy MJ, O’Donovan N, Brennan DJ, Gallagher WM, Ryan BM. Survivin: a promising tumor biomarker. Cancer Lett. 2007;2491: $49-60$.

6. Altieri DC. Survivin, cancer networks and pathway-directed drug discovery. Nat Rev Cancer. 2008;81:61-70.

7. Pennati M, Folini M, Zaffaroni N. Targeting survivin in cancer therapy. Expert Opin Ther Targets. 2008;124:463-76.

8. Pennati M, Folini M, Zaffaroni N. Targeting survivin in cancer therapy: fulfilled promises and open questions. Carcinogenesis. 2007;286:1133-9.

9. Chantalat L, Skoufias DA, Kleman JP, Jung B, Dideberg O, Margolis RL. Crystal structure of human survivin reveals a bow tie-shaped dimer with two unusual alpha-helical extensions. Mol Gell. 2000;61:183-9.

10. Ryan BM, O'Donovan N, Duffy MJ. Survivin: a new target for anti-cancer therapy. Cancer Treat Rev. 2009;35:553-62.

11. Whitesell L, Lindquist SL. Hsp90 and the chaperoning of cancer. Nat Rev Cancer. 2005;5:761-72.

12. Fortugno P, Beltrami E, Plescia J, Fontana J, Pradhan D, Marchisio PC, et al. Regulation of survivin function by Hsp90. Proc Natl Acad Sci U S A. 2003;100:13791-6.

13. Plescia J, Salz W, Xia F, Pennati M, Zaffaroni N, Daidone MG, et al. Rational design of Shepherdin, a novel anticancer agent. Cancer Cell. 2005; 7:457-67.

14. Meli M, Pennati M, Curto M, Daidone MG, Plescia J, Toba S, et al. Small-molecule targeting of heat shock protein 90 chaperone function: rational identification of a new anticancer lead. J Med Chem. 2006;49:7721-30.

15. Kizek R, Adam V, Hrabeta J, Eckschlager T, Smutny S, Burda JV, et al. Anthracyclines and ellipticines as DNA-damaging anticancer drugs: recent advances. Pharmacol Ther. 2012;133:26-39.

16. Smith L, Watson MB, O'Kane SL, Drew PJ, Lind MJ, Cawkwell L. The analysis of doxorubicin resistance in human breast cancer cells using antibody microarrays. Mol Cancer Ther. 2006;5:2115-20.

17. Minotti G, Menna P, Salvatorelli E, Cairo G, Gianni L. Anthracyclines: molecular advances and pharmacologic developments in antitumor activity and cardiotoxicity. Pharmacol Rev. 2004;56:185-229.

18. Daglioglu G, Okutucu B. Synthesis and characterization of AICAR and DOX conjugated multifunctional nanoparticles as a platform for synergistic inhibition of cancer cell growth. Bioconjug Chem. 2016;27:1098-111.

19. Zaffaroni N, Pennati M, Colella G, Perego P, Supino R, Gatti L, et al. Expression of the anti-apoptotic gene survivin correlates with taxol resistance in human ovarian cancer. Cell Mol Life Sci. 2002;59:1406-12.

20. Van Geelen CM, De Vries EG, De Jong S. Lessons from TRAILresistance mechanisms in colorectal cancer cells: paving the road to patient-tailored therapy. Drug Resist Updat. 2004;7:345-58.

21. Asanuma K, Moriai R, Yajima T. Survivin as a radio-resistance factor in pancreatic cancer. Jpn J Cancer Res. 2000;91:1204-9.

22. Olie RA, Simoes-Wust AP, Baumann B, Leech SH, Fabbro D, Stahel RA, et al. A novel antisense oligonucleotide targeting survivin expression induces apoptosis and sensitizes lung cancer cells to chemotherapy. Cancer Res. 2000;60:2805-9.

23. Li F, Altieri DC. Transcriptional analysis of human survivin gene expression. Biochem J. 1999;344(Pt 2):305-11.

24. Li F, Ambrosini G, Chu EY, Plescia J, Tognin S, Marchisio PC, et al. Control of apoptosis and mitotic spindle checkpoint by survivin. Nature. 1998;396:580-4.

25. Tamm I, Wang Y, Sausville E, Scudiero DA, Vigna N, Oltersdorf $\mathrm{T}$, et al. IAP-family protein survivin inhibits caspase activity and apoptosis induced by Fas (CD95), Bax, Caspases, and Anticancer Drugs. Cancer Res. 1998;58:5315-20. 